Anteh J.D., Mostyakova A.A., Kalimullin M.I., Timofeeva O.A.

Effect of mineral fertilizers on the variability of phytochemicals in kale

Электронный научно-производственный журнал

«АгроЭкоИнфо "

\title{
Effect of mineral fertilizers on the variability of phytochemicals in kale
}

\author{
Anteh J.D., Mostyakova A.A., Kalimullin M.I., Timofeeva O.A. \\ Kazan Federal University
}

\begin{abstract}
The effect of five mineral nutrients on the variability of the content of biochemical compounds, such as flavonoids, phenolic compounds, vitamin $C$, carotenoids and the antioxidant activity of kale (Brassica Oleracea var. sabellica) collected at the edible maturity stage. Manipulation of the phytochemical composition of the kale cabbage using mineral fertilizers was evident in the results achieved. The various mineral nutrients used had different effects on the content of the studied phytochemicals. The content of flavonoids and carotenoids did not decrease with any of the various mineral nutrients used. Contrary to recent research suggesting that rare earth elements are good stimulators of secondary metabolite accumulation, our results showed a decrease in the content of phenolic compounds in plants fertilized with neodymium. The total antioxidant activity increased under the influence of NPK and humate, which correlated with the highest content of soluble phenolic compounds and flavonoids in kale leaves. Low doses of $N$ have a positive effect on these indicators. Mineral supplements of trace elements also had a stimulating effect on the accumulation of the studied substances. However, in addition to trace elements, a significant role is played by the presence of humic acids (in humate), which together with trace elements have the maximum stimulating effect on the content of the substances under study.
\end{abstract}

Keywords: MINERAL FERTILIZERS, ANTIOXIDANT PHYTOCHEMICALS, PHENOLIC COMPOUNDS, CAROTENOID, ANTIOXIDATIVE ACTIVITY, VITAMIN C, FLAVONOIDS, BRASSICA VEGETABLES

In recent years, one of the most important agricultural crops that is popularly known for its health benefits particularly for curing or reducing the risk of cancer, diabetes and heart diseases is kale (Brassica Oleracea var. sabellica). This property of kale is due to the high content of health-promoting bioavailable phytochemicals such as flavonoids, vitamin $\mathrm{C}$, phenolic compounds, carotenoids as well as its antioxidative activity. These phytochemicals produced via the secondary metabolic pathway are antiinflammatory, antihepatotoxic, effective antioxidants, antiallergenic, etc. Their role is to protect plants from pathogens and unfavourable environmental effects [1,2]. Although humans have evolved with endogenous antioxidant systems to scavenge free radicals, the 
Anteh J.D., Mostyakova A.A., Kalimullin M.I., Timofeeva O.A.

Effect of mineral fertilizers on the variability of phytochemicals in kale

Электронный научно-производственный жсурнал

«АгроЭкоИнфо»

inefficiency of these defence systems has increased our dependency on dietary antioxidants to diminish the cumulative effects of oxidative damage.

Flavonoids are identified as antioxidants because they scavenge and suppress reactive oxygen species formation by inhibiting enzymes or chelating trace elements involved in free radical production. Our study focuses on the predominant flavonol quercetin found in vegetables [3, 4].

Phenolic compounds play an important role in the electron transport chain in respiration and photosynthesis by protecting cells from adverse effects. Carotenoids and vitamin $\mathrm{C}$ are known as protective dietary antioxidants $[5,6]$.

Dark green leafy kale (Brassica Oleracea var. Sabellica) which is the object of study is a Brassicaceae crop like cabbage, broccoli, cauliflower and Brussels sprouts. Brassicaceae vegetables among the many varieties of vegetables have received the most attention because of their unique contents and are considered to nurture human health through continuous consumption [7]. The health beneficial phytochemicals abundant in kale are affected by both abiotic and biotic factors [8]. In this article, we provide results of the effect of mineral nutrients such as NPK, biostim, energen, humate and neodymium on the content of phytochemicals in kale (Brassica Oleracea var. Sabellica). The need for scientific data on the variability of kale's phytochemical content depending on the type of mineral nutrient used will accurately guide constructive manipulation of abiotic factors to obtain desired results.

\section{Methods}

Kale seedlings were transferred from the laboratory to be sown in the fields in July 2019, after processing the seeds in a Petri dish for 7 days. The following mineral nutrients were applied to each experiment variant - biostim (a mixture of macro - and microelements, 11/ha), NPK $(15: 15: 20,20 \mathrm{~kg} / \mathrm{ha})$, humate $(\mathrm{K}, \mathrm{Na}$ - salts of humic acids and microelements, $80 \mathrm{~g} / \mathrm{l}), \mathrm{Nd}\left(10^{-5}\right)$ and energen ( $\mathrm{K}$ salts of humic acids and trace elements, $80 \mathrm{~g} / \mathrm{l}$ ) for a day after which it was treated with water for the remaining days. The control variant had only water for 7 days. The content of total flavonoids (Fig. 1), total phenolics (Fig. 2), antioxidative activity (Fig. 5), total carotenoid (Fig. 4) and Vitamin C (Fig. 1) of edible matured kale leaves were determined. Phenolic compounds were determined by the modified Folin-Ciocalteu method [9] at a wavelength of $725 \mathrm{~nm}$. The content of phenolic compounds was determined in terms of gallic acid. Flavonoids were determined by reaction with $\mathrm{AlCl} 3$ by the colourimetric method [10] at a wavelength of $420 \mathrm{~nm}$. The antioxidant activity of the samples was determined by their ability to 
Anteh J.D., Mostyakova A.A., Kalimullin M.I., Timofeeva O.A.

Effect of mineral fertilizers on the variability of phytochemicals in kale

Электронный научно-производственный журнал

«АгроЭкоИнфор

inhibit the autooxidation of epinephrine in vitro and thereby prevent the formation of reactive oxygen species [11]. The quantitative determination of ascorbic acid content in tissues was performed using potassium hexacyanoferrate [12], the spectrophotometric method for determining the content of pigments was applied in this work [13]. Experiments were conducted in three independent biological repeats. Statistical data processing was performed using the software GraphPad prism, v. 8.4. The reliability of the difference was determined by the criterion of single-factor analysis of variance $*=\mathrm{p} \leq 0.05$.

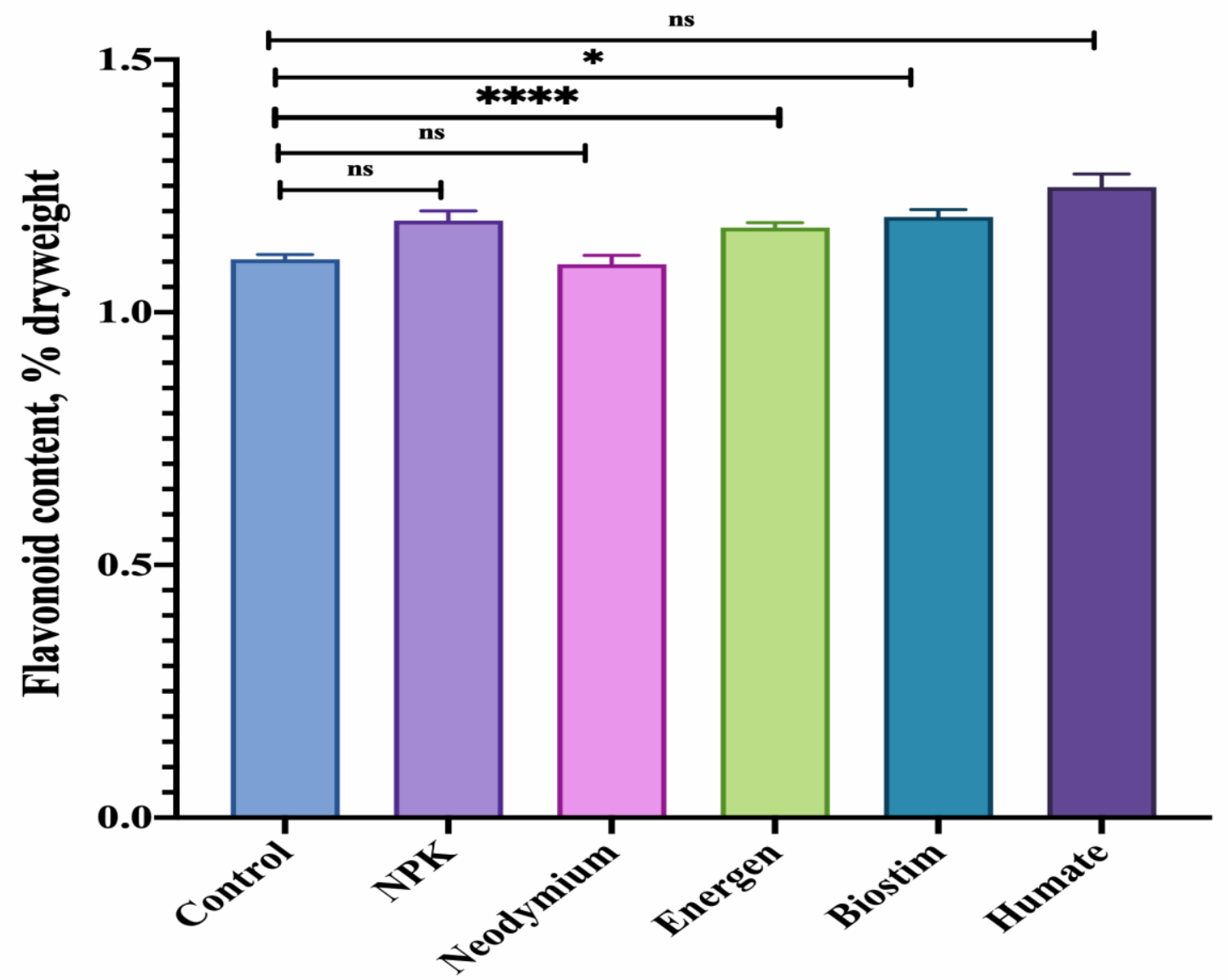

Fig. 1. The effect of mineral fertilizers on the content of flavonoids in kale (Brassica Oleracea var. Sabellica)

Note: Error bars signify 95\% confidence intervals. Tukey's honest significant difference (HSD) post-hoc test was used for multiple pairwise comparisons. The symbols ns, *, **, ***, ****, represent $\mathrm{P}>0.05, \mathrm{P} \leq 0.05, \mathrm{P} \leq 0.01, \mathrm{P} \leq 0.001$, and $\mathrm{P} \leq 0.0001$, respectively.

\section{Results and discussion}

Consumer demand for safe and natural ways to treat diseases and minimize health risks is growing worldwide, while there is a decline in interest in the use of synthetic 
Anteh J.D., Mostyakova A.A., Kalimullin M.I., Timofeeva O.A.

Effect of mineral fertilizers on the variability of phytochemicals in kale

Электронный научно-производственный журнал

«АгроЭкоИнфо»

chemicals [14]. Kale (Brassica Oleracea var. sabellica) as a nutraceutical is a very promising vegetable crop and can be used as a food product, as well as therapeutically due to its rich phytochemical composition.

In our research, mineral nutrients were used to manipulate the composition of these healthy biologically active compounds. The graph shows that the treatment of seeds with mineral nutrients affects the level of flavonoids to some extent. NPK, energen, biostim and humate increased the content of flavonoids in cabbage by $6.9 \%, 5.7 \%, 7.6 \%$ and $13 \%$, respectively. In samples fertilized with neodymium, the content of flavonoids did not differ statistically from that of the control.

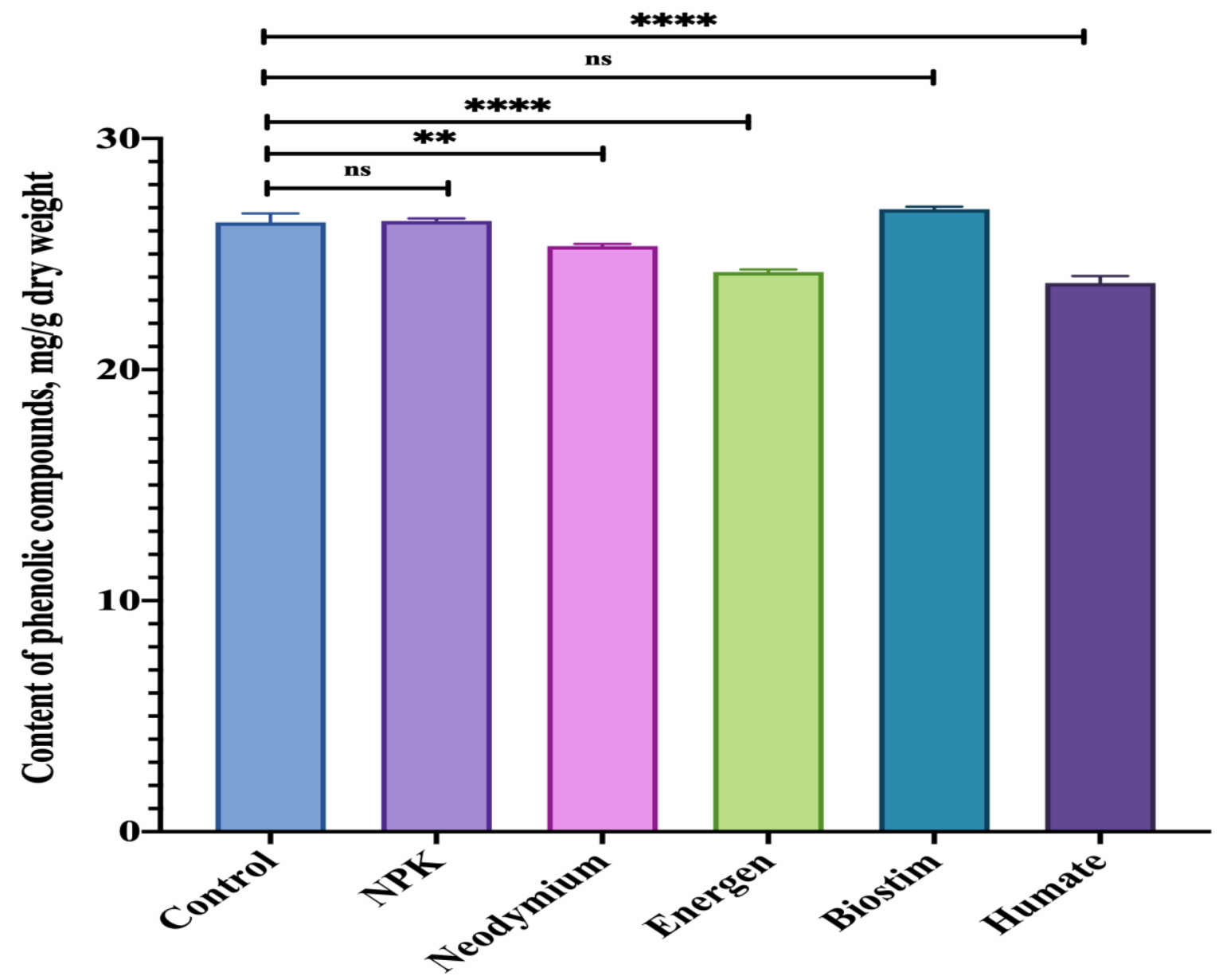

Fig. 2. The effect of mineral fertilizers on the content of phenolic compound in kale (Brassica Oleracea var. sabellica)

Note: Error bars signify 95\% confidence intervals. Tukey's honest significant difference (HSD) post-hoc test was used for multiple pairwise comparisons. The symbols ns, *, **, ***, ****, represent $\mathrm{P}>0.05, \mathrm{P} \leq 0.05, \mathrm{P} \leq 0.01, \mathrm{P} \leq 0.001$, and $\mathrm{P} \leq 0.0001$, respectively. 
Anteh J.D., Mostyakova A.A., Kalimullin M.I., Timofeeva O.A.

Effect of mineral fertilizers on the variability of phytochemicals in kale

Электронный научно-производственный жсурнал

«АгроЭкоИнфо»

Treatment of seeds with mineral nutrients had a differentiated effect on the content of phenolic compounds. NPK and Biostim led to a slight but insignificant increase in the content of phenols $(0.2 \%$ and $2.2 \%$ respectively; $\mathrm{p}>0.05)$. Neodymium, energen and humate reduced the total phenol content by $4 \%, 8 \%$ and $11 \%$, respectively.

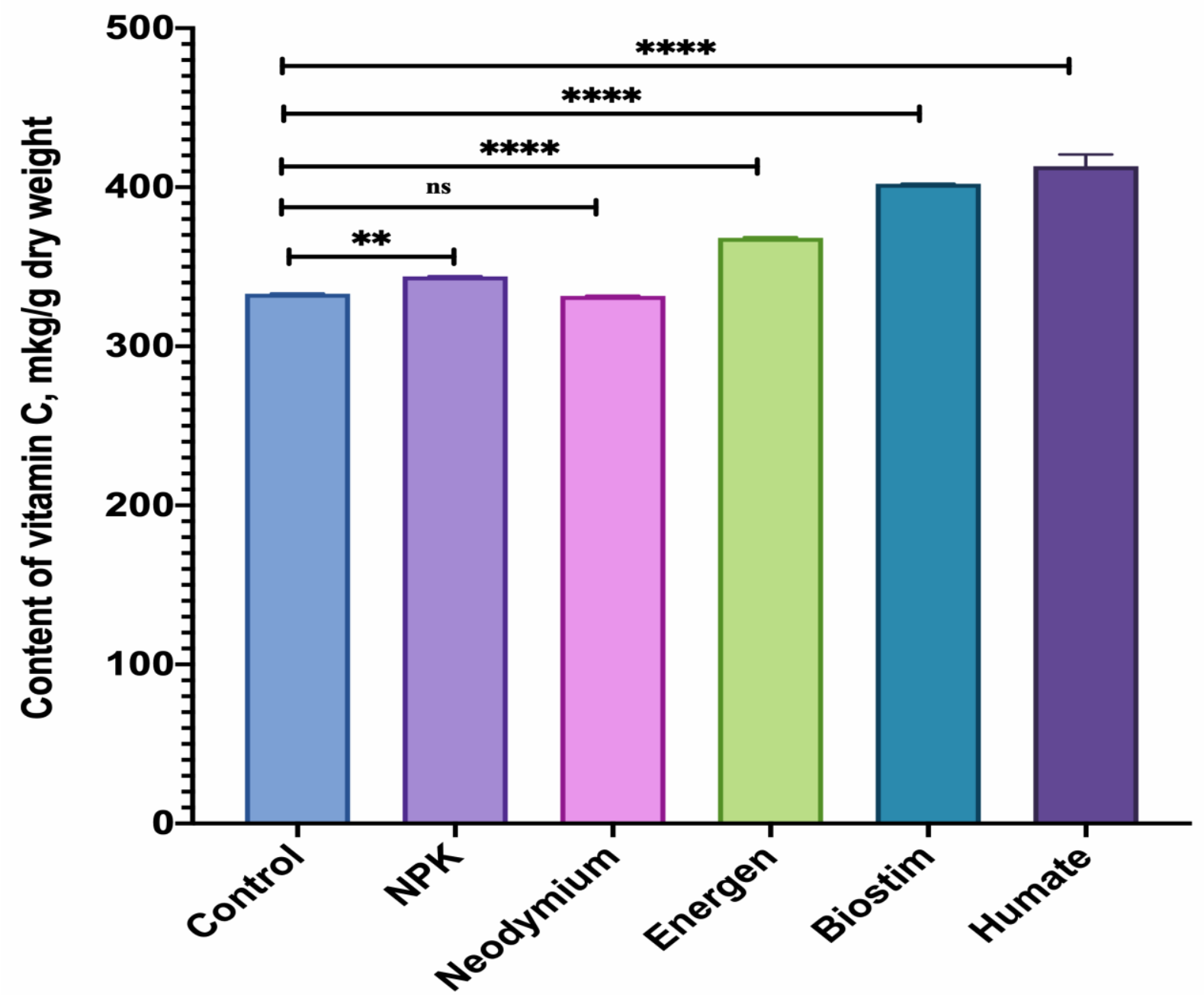

Fig. 3. The effect of mineral fertilizers on the content of vitamin $\mathrm{C}$ in kale (Brassica oleracea var. sabellica)

Note: Error bars signify 95\% confidence intervals. Tukey's honest significant difference (HSD) post-hoc test was used for multiple pairwise comparisons. The symbols ns, *, **, ***, ****, represent $\mathrm{P}>0.05, \mathrm{P} \leq 0.05, \mathrm{P} \leq 0.01, \mathrm{P} \leq 0.001$, and $\mathrm{P} \leq 0.0001$, respectively.

The content level of vitamin $\mathrm{C}$ changed after treatment with mineral supplements.NPK, Energen, Biostim and Humate increased the content of vitamin $\mathrm{C}$ in kale by $3 \%, 11 \%, 21 \%$ and $24 \%$, respectively. Humate showed the highest positive effect on the content of vitamin C. In samples fertilized with neodymium, the content of vitamin C non-significantly decreased by $0.5 \%$. 
Anteh J.D., Mostyakova A.A., Kalimullin M.I., Timofeeva O.A.

«АгроЭкоИнфо»

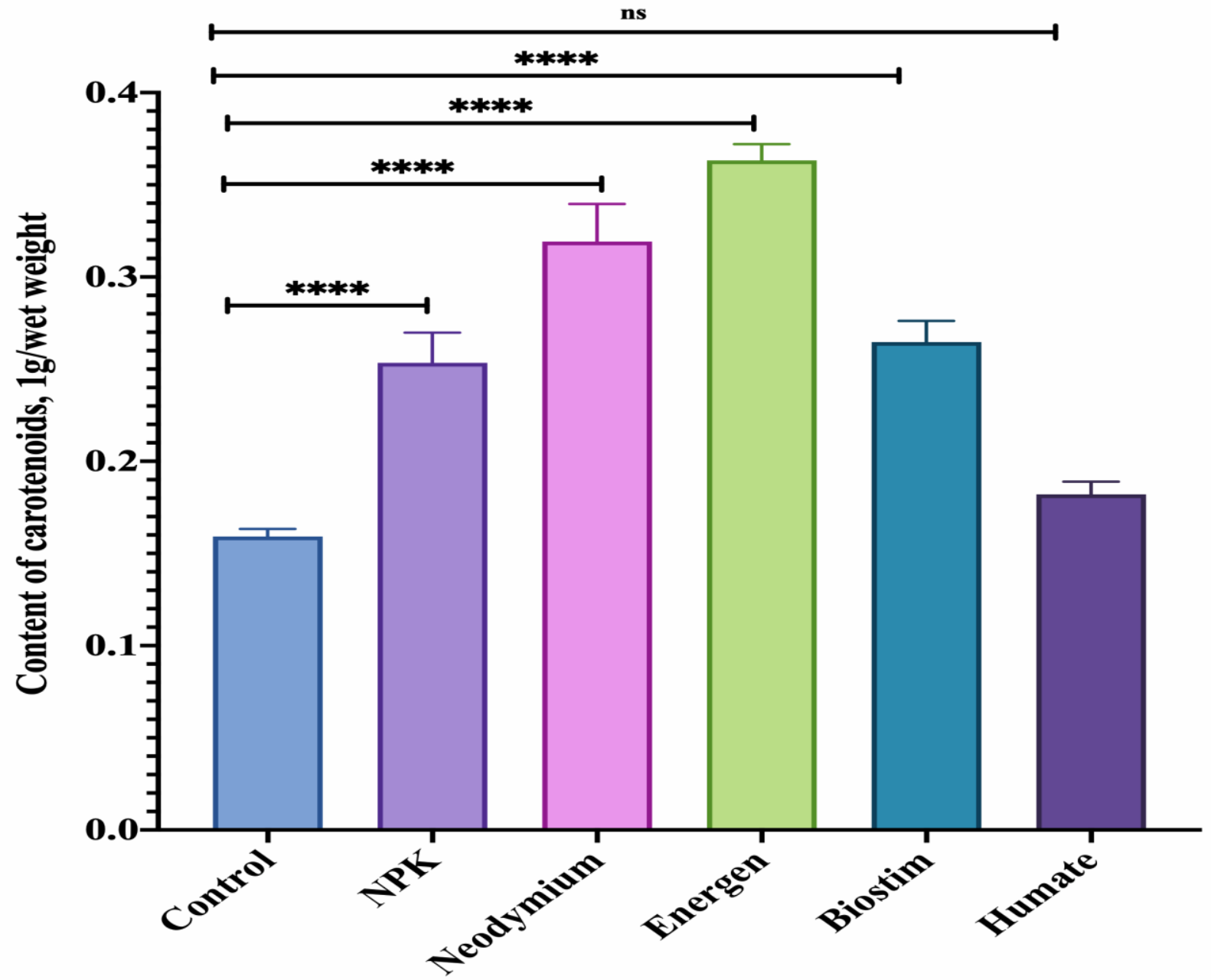

Fig. 4. The effect of mineral fertilizers on the content of carotenoids in kale (Brassica oleracea var. sabellica)

Note: Error bars signify 95\% confidence intervals. Tukey's honest significant difference (HSD) post-hoc test was used for multiple pairwise comparisons. The symbols ns, *, **, ***, ****, represent $\mathrm{P}>0.05, \mathrm{P} \leq 0.05, \mathrm{P} \leq 0.01, \mathrm{P} \leq 0.001$, and $\mathrm{P} \leq 0.0001$, respectively.

All mineral nutrients increased the carotenoid content in kale: NPK, neodymium, energen, biostim and humate increased the carotenoid content of kale by $59 \%, 101 \%, 128 \%$, $66 \%$ and $14 \%$, respectively. In plants fertilized with energen, we observed the highest positive effect on the content of carotenoids. Factors that affect the biosynthesis of carotenoids are certain enzymes and essential precursors in plants. The presence of mineral nutrients that are sources of co-factors that facilitate these metabolic reactions affects the quantity of carotenoid synthesized. This can explain the high carotenoid content measured in all the analyzed variants in our studies. 
Anteh J.D., Mostyakova A.A., Kalimullin M.I., Timofeeva O.A.

Effect of mineral fertilizers on the variability of phytochemicals in kale

Электронный научно-производственный журнал

«АгроЭкоИнфо»

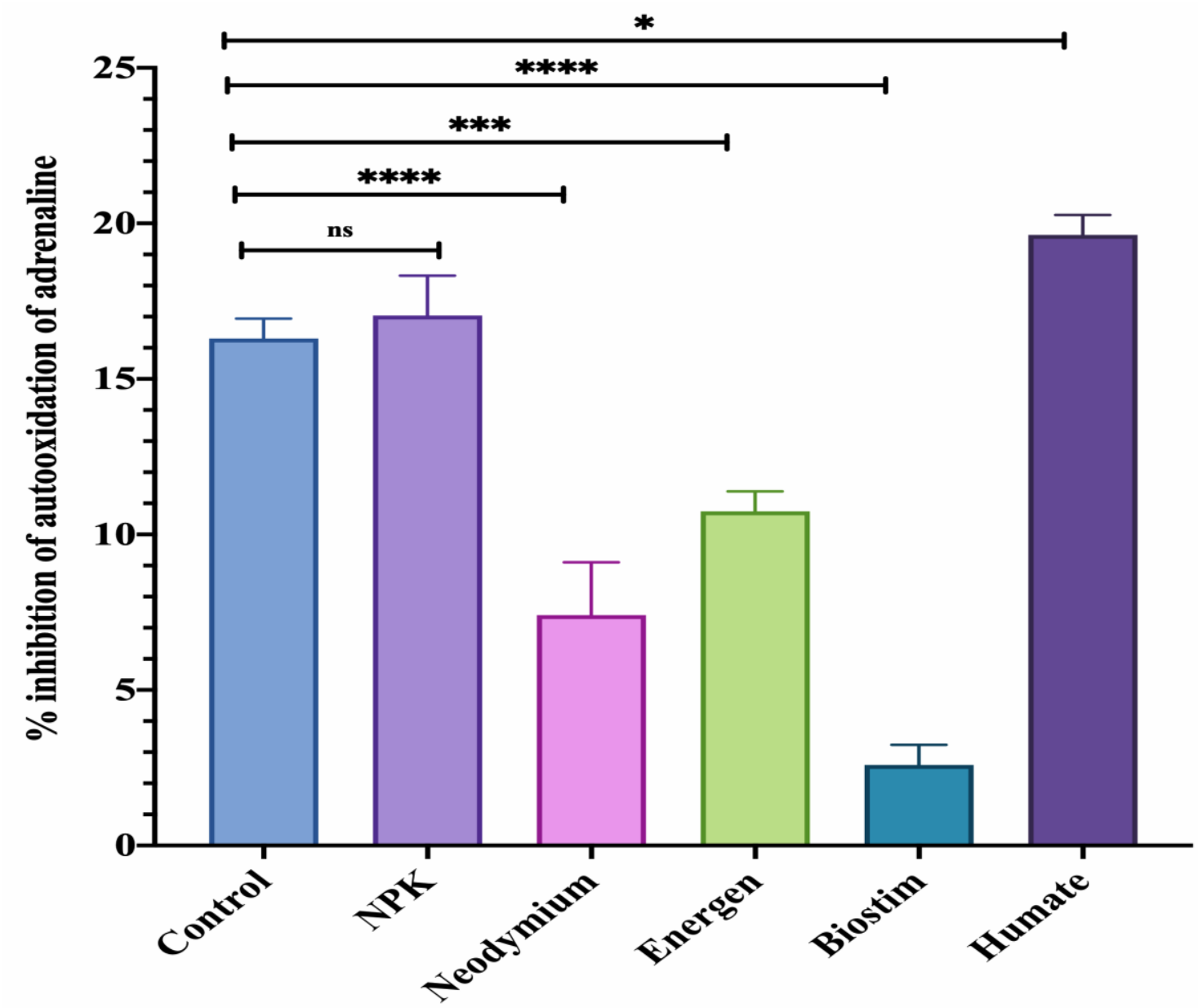

Fig. 5. The effect of mineral fertilizers on antioxidative activity in kale (Brassica oleracea var. sabellica)

Note: Error bars signify 95\% confidence intervals. Tukey's honest significant difference (HSD) post-hoc test was used for multiple pairwise comparisons. The symbols ns, *, **, ***, ****, represent $\mathrm{P}>0.05, \mathrm{P} \leq 0.05, \mathrm{P} \leq 0.01, \mathrm{P} \leq 0.001$, and $\mathrm{P} \leq 0.0001$, respectively.

In plants fertilized with NPK and humate, the antioxidant activity in kale cabbage increased by $5 \%$ and $20 \%$, respectively. And treatment of seeds with neodymium, energen and biostim resulted in a decrease in antioxidant activity by $55 \%, 34 \%$ and $84 \%$, respectively. Scientific research shows that since phenols are formed along the same shikimic acid pathway as aromatic amino acids, nitrogen availability affects the concentration of phenols. This biochemical compromise between the synthesis of phenols and proteins has been demonstrated for many plant species. It was identified that nitrogen deficiency increased the mRNA levels of such enzymes involved in flavonoid synthesis as chalcone synthesis and dihydroflavonol reductase. However, there are few studies on the influence of nitrogen levels on the total content of phenolic compounds, and they are 
Anteh J.D., Mostyakova A.A., Kalimullin M.I., Timofeeva O.A.

Effect of mineral fertilizers on the variability of phytochemicals in kale

Электронный научно-производственный жсурнал

«АгроЭкоИнфо »

quite contradictory. In fuzzy reactions of phenols, changes in nitrogen levels were observed [15]. Bénard et al. described a tendency to increase the content of certain phenolic compounds with a decrease in $\mathrm{N}$ levels [16]. At the same time, it is shown that the positive effect of $\mathrm{N}$ deficiency on the content of phenols by an increase in the activity of phenylalanine ammonia-lyase occurs only during prolonged nitrogen starvation due to inhibition of primary metabolism. For field conditions, nitrogen deficiency can be mitigated or exacerbated by climate conditions. For these reasons, the results on the effect of $\mathrm{N}$ on the accumulation of phenolic compounds level may differ in the studies of different authors. In our research, we observed an increase in the content of flavonoids and soluble phenolic compounds when kale was treated with the mineral nutrient NPK. There is a general opinion that nitrogen fertilizers reduce the vitamin C content in leafy vegetables [15]. At the same time, some works on cabbage have demonstrated other results. Depending on the type, there was a decrease, no effect, or even an increase in the level of vitamin $\mathrm{C}$ with an increase in $\mathrm{N}$. In the case of kale, the optimal dose for the highest amounts of

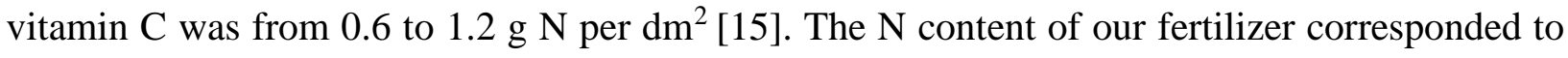
$0.6 \mathrm{~g} / \mathrm{dm}^{2}$, which corresponds to the literature data. In light of this connection, it seems that a small stimulating effect of this supplement on the content of vitamin $\mathrm{C}$ was observed. The other mineral additives containing various trace elements probably have their positive effect associated with the activation of enzymes involved in the synthesis of the studied compounds.

The antioxidant activity, which generally characterizes the presence of a wide variety of substances with antioxidant activity, in our studies increased when fertilized with NPK and humate. This is not consistent with data in research by Giorgi et al. [17], which describes a decrease in total antioxidant activity with an increase in $\mathrm{N}$ levels. At the same time, the variety specificity of the overall antioxidant activity is described, which depends on the content of compounds with antioxidant activity. The total antioxidant activity strongly correlates with the content of phenolic compounds and especially flavonoids. As can be seen from the data, humate and NPK increased the content of soluble phenolic compounds and flavonoids the most.

\section{Summary}

The various mineral nutrients used had different effects on the content of the studied phytochemicals. Contrary to recent research suggesting that rare earth elements are good stimulators of secondary metabolite accumulation, our results showed a decrease in the phenolic compounds content in plants fertilized with neodymium. The total antioxidant activity increased 
Anteh J.D., Mostyakova A.A., Kalimullin M.I., Timofeeva O.A.

Effect of mineral fertilizers on the variability of phytochemicals in kale

Электронный научно-производственный жсурнал

«АгроЭкоИнфо »

under the influence of NPK and humate. It was these fertilizers that increased the content of soluble phenolic compounds and flavonoids most. Low doses of $\mathrm{N}$ have a positive effect on these indicators. Mineral supplements of trace elements also had a stimulating effect on the accumulation of the studied substances. However, in addition to trace elements, a significant role is played by the presence of humic acids (in humate), which together with trace elements have the maximum stimulating effect on the content of the substances under study.

\section{Conclusions}

The results indicate the need for furthermore detailed research to determine the most optimal conditions for growing Kale cabbage with a balanced phytochemical composition.

\section{Acknowledgements}

The work is performed according to the Russian Government Program of Competitive Growth of Kazan Federal University.

\section{Bibliography}

1. Lefsrud M.G., Kopsell D.A., Sams C.E. Irradiance from distinct wavelength light-emitting diodes affect secondary metabolites in kale // HortScience. - 2008. - Vol. 43. - № 7. - P. 2243-2244.

2. Redondo-Blanco S., Fernández J., López-Ibáñez S., Miguélez E.M., Villar C.J., Lombó F. Plant Phytochemicals in Food Preservation: Antifungal Bioactivity: A Review // Journal of Food Protection. - 2020. - Vol. 83. - №1 . - P. 163-171.

3. Bjørklund G., Chirumbolo S. Role of oxidative stress and antioxidants in daily nutrition and human health // Nutrition. - 2017. - Vol. 33. - P. 311-321.

4. Pandey K.B., Rizvi S.I. Plant polyphenols as dietary antioxidants in human health and disease // Oxidative medicine and cellular longevity. - 2009. - Vol. 2. - P. 9

5. Chu Y.F., Sun J.I. E., Wu X., Liu R. H. Antioxidant and antiproliferativeactivities of common vegetables // Journal of agricultural and food chemistry. - 2002. - Vol. 50. - №23. - P. 6910-6916.

6. Fiedor J. Potential role of carotenoids as antioxidants in human health and disease // Nutrients. - 2014. - Vol. 6. - №2. - P. 466-488.

7. Rana M.K., Mamatha N.C. Kale. In Vegetable Crop Science // CRC Press. - 
Anteh J.D., Mostyakova A.A., Kalimullin M.I., Timofeeva O.A.

Effect of mineral fertilizers on the variability of phytochemicals in kale

2017. - P. 383- 392.

8. Guo R., Shi L., Jiao Y., Li M., Zhong X., Gu F., Liu Q., Xia X., Li H. Metabolic responses to drought stress in the tissues of drought-tolerant and droughtsensitive wheat genotype seedlings // AoB Plants. - 2018. - Vol. 10. - №2. - DOI: 10.1093/aobpla/ply016.

9. Velioglu Y. S., Mazza G., Gao L., Oomah B. D. Antioxidant activity and total phenolics in selected fruits, vegetables, and grain products // Journal of agricultural and food chemistry. - 1998. - Vol. 46. - № 10 - P. 4113-4117.

10. Zhishen J., Mengcheng T., Jianming W.The determination of flavonoid contents in mulberry and their scavenging effects on superoxide radicals // Food chemistry. - 1999. - Vol. 64. - №4. - P. 555-559.

11. Сирота Т.В. Способ определения антиоксидантной активности супероксиддисмутазы и химических соединений // Патент РФ. 2144674. - 2000.

12. Полевой В.В., Максимов Г.Б. Методы биохимического анализа растений. Учебное пособие. Изд-во Ленингр. ун-та. - 1978. - 192 с.

13. Грекова И.В., Чукуриди С.С., Тосунов Я.К. Определение содержания фотосинтетических пигментов у представителей рода PhiladelphusL. в условиях Краснодара // Аграрная Россия. - 2018. - Vol. 10. - Р. 14-16.

14. Brewer M. S. Natural antioxidants: sources, compounds, mechanisms of action, and potential applications // Comprehensive reviews in food science and food safety. - 2011. - Vol. - 10. - №4. - P. 221-247.

15. Łata B. Variability in enzymatic and non-enzymatic antioxidants in red and green-leafy kale in relation to soil type and N-level // ScientiaHorticulturae. - 2014. Vol. 168. - P. 38-45.

16. Benard C., Gautier H., Bourgaud F., Grasselly D., Navez B., Caris-Veyrat C., Weiss M., Genard M. Effects of low nitrogen supply on tomato (Solanumlycopersicum) fruit yield and quality with special emphasis on sugars, acids, ascorbate, carotenoids, and phenolic compounds // Journal of agricultural and food chemistry. - 2009. -Vol.57. №10. - P. 4112-4123.

17. Giorgi A., Mingozzi M., Madeo M., Speranza G., Cocucci M. Effect of nitrogen starvation on the phenolic metabolism and antioxidant properties of yarrow (Achilleacollina Becker ex Rchb.) // Food Chemistry. - 2009. -Vol. 114. - №1 . - P. 204211.

\section{Citation:}

Anteh J.D., Mostyakova A.A., Kalimullin M.I., Timofeeva O.A. The effect of mineral fertilizers on the variability of phytochemicals in cale [Electron. resource] // AgroEcoInfo: Electronic scientific and production journal. - 2021. - No. 1. - Access mode: http://agroecoinfo.narod.ru/journal/STATYI/2021/1/st_108_eng.pdf.

DOI: https://doi.org/10.51419/202111080. 